\title{
Control of chromium dopant content in optical ceramics Cr:YAG
}

\author{
O.V.Gayduk \\ STC "Institute for Single Crystals", National Academy of Sciences of \\ Ukraine, 60 Nauky Ave., 61001 Kharkiv, Ukraine
}

\section{Received November 9, 2016}

\begin{abstract}
Spectrophotometric determination of chromium in the presence of predominating yttrium and aluminum quantities was investigated by the method based on the reaction Cr(VI) with diphenylcarbazide. The optimum conditions of $\mathrm{Cr}$ (III) oxidation by potassium permanganate were established. A spectrophotometric technique for determination of 0.005-0.3\% of chromium in Cr-doped yttrium aluminum garnet ceramics was developed. The determination error is $1-5 \%$.

Keywords: Cr(VI), Cr(III), diphenylcarbazide, potassium permanganate, oxidation, yttrium aluminum garnet, spectrophotometry.

Проведены исследования по спектрофотометрическому определению хрома в присутствии преобладающих количеств иттрия и алюминия методом, основанным на реакции взаимодействия хрома(VI) с дифенилкарбазидом. Установлены оптимальные условия окисления хрома(III) перманганатом калия. Разработана методика определения 0,0050,3 хрома в керамике иттрий алюминиевого граната, допированного хромом. Относительная погрешность определения составляет 1-5\%.
\end{abstract}

Контроль вмісту добавки хрому в оптичній кераміці Cr:YAG. O.В.Гайдук.

Проведено дослідження з спектрофотометричного визначення хрому у присутності переважаючих кількостей ітрію та алюмінію методом, заснованим на реакції взаємодії хрому(VI) з дифенілкарбазидом. Встановлено оптимальні умови окиснення хрому(III) перманганатом калію. Розроблено методику визначення 0,005-0,3\% хрому у кераміці ітрій алюмінієвого гранату, допованого хромом. Відносна похибка визначення складає 1-5 \%.

\section{Introduction}

IR-lasers are widely used in various fields of science, technology and medicine. Active elements of most of them are based on single crystals with the structure of garnet doped with rare-earth elements. Nowadays great attention is being paid to composite Q-switching laser elements which consists of a layer of active laser medium such as yttrium aluminum garnet (YAG) doped with ions of rare-earth elements and the Q-switching layer Cr:YAG. Such a composition makes it possible to obtain short and high-power radiation pulses [1,2]. The process of preparation of the ceramics con- sists of several technological stages, in particular, mixing of oxide powders in accordance with the stoichiometry, their homogenization and drying, vacuum synthesis and annealing in air. Determination of the chemical composition of the product at each stage of the technological process permits to effectively and purposefully control the synthesis parameters for the obtaining of the ceramics with predetermined properties.

Determination of microgram quantities of chromium in different matrices is realized by a number of analytical methods such as UV-Vis spectrophotometry [3-7], chemiluminescence [8], flame atomic absorption spectrometry $[9,10]$, inductively coupled 
plasma atomic emission spectrometry (ICPAES) [11], inductively coupled plasma-mass spectrometry (ICP-MS) [12]. Sensitivity of the methods of chemiluminescence and flame atomic absorption spectrometry is not always sufficient for determination of low concentrations of chromium. Atomic emission spectrometry and mass spectrometry are express methods characterized by low limits of determination of a large number of elements. However, these methods require availability of expensive equipments and the presence of experienced qualified staff. Moreover, for obtaining reliable results of the analysis it is necessary to correctly perform blank test taking into account impurity from different sources and correspondence of the relevant reference samples to the analyzed material in constructing of calibration dependences.

For determination of chromium in Cr:YAG optical ceramics we chose the spectrophotometric method based on the reaction of chromium(VI) with 1,5-diphenylcarbazide (DPC) [13-17]. Determination of chromium with diphenylcarbazide in manycomponent objects is realized using extraction [18, 19] or ion exchange [20]. We could not find any papers devoted to determination of chromium in the presence of predominating concentrations of yttrium and aluminium in the literature.

Diphenylcarbazide is a very sensitive $(\varepsilon=$ $4.17 \cdot 10^{-4}$ at $\lambda_{\max }=546 \mathrm{~nm}$ ) and rather selective reagent. In sulfuric-acid medium Cr(VI) oxidizes diphenylcarbazide to diphenylcarbazone. The oxidated form of the reagent interacts with the obtained Cr(III) that leads to the formation of a redviolet positively charged complex compound. The complex is stable in 0.025$0.1 \mathrm{M}$ solution of sulfuric acid, in a medium of higher acidity it decomposes. Chromium (III) solution cannot be used for the analysis, since it forms stable aqua- and halogen aqua-complexes which decompose very slowly [21]. On the contrary, the reaction between $\mathrm{Cr}(\mathrm{VI})$ and diphenylcarbazide is instantaneous. Therefore, prior to determination chromium, $\mathrm{Cr}$ (III) is to be oxidized to Cr(VI). Ammonium persulphate [22] or potassium permanganate [18] is used for the oxidation of Cr(III) in an acid medium.

The conditions of $\mathrm{Cr}$ (III) oxidation and the reaction of chromium (VI) with 1,5 diphenylcarbazide have been studied in this work with the intention of its use for spectrophotometric determination of microgram quantities of chromium in the presence of $Y$ and $\mathrm{Al}$, the content of which in the analyzed sample exceeding the one of chromium by several hundred fold.

\section{Experimental}

All the utilized reagents were analytically pure. Deionized water were used in the preparation of all solutions. Was used $0.1 \%$ ethanol solution of diphenylcarbazide. Twice recrystallized potassium bichromate was applied as a standard. All absorbance measurements were made with spectrophotometer SF-2000.

The ceramic sample was melted with a mixture of sodium carbonate and sodium tetraborate $(2: 1)$ followed by dissolution of the melt in hydrochloric acid. Oxidation of chromium and its determination with diphenylcarbazide is realized in a sulphuric medium, however, in $\mathrm{H}_{2} \mathrm{SO}_{4}$ the melt of the sample does not dissolve completely. Excess of hydrochloric acid before determining chromium was removed by evaporation with sulfuric acid till white vapor was formed.

\section{Results and discussion}

As shown in our research, the process of oxidation of $\mathrm{Cr}$ (III) to $\mathrm{Cr}(\mathrm{VI})$ with ammonium persulfate in the solution of the ceramics is rather slow and incomplete. Therefore we preferred to use potassium permanganate for this purpose.

It is known that in solutions potassium permanganate spontaneously decomposes with release of oxygen and formation of manganese dioxide precipitate. The degree of oxidation depends on the concentration of potassium permanganate, the solution acidity, the time and the temperature. Moreover, the process decomposition is catalytically stimulated by the presence of $\mathrm{Mn}^{2+}$ and $\mathrm{MnO}_{2}$ in the solution. Therefore, for the obtaining of correct and reproducible results of chromium determination it is necessary to choose optimum oxidation conditions.

Cr(III) oxidation was realized in a beaker covered with watch glass. The solution was heated using an electric furnace for 2025 min. The optimum concentration of potassium permanganate for oxidation is 6$7 \cdot 10^{-4}$ mole/l in 0.06-0.08 $\mathrm{M} \mathrm{H}_{2} \mathrm{SO}_{4}$. The increase of $\mathrm{KMnO}_{4}$ concentration, the solution acidity or the time of heating lead to the formation of $\mathrm{MnO}_{2}$. The latter slowly dissolves that increases excessive volume of the reducer and, consequently, to underestimation of the results of chromium determination. 
Table 1. Testing results of chromium determination technique on model mixtures $(n=5-6 ; P=0.95)$

\begin{tabular}{|c|c|c|c|c|}
\hline \multicolumn{2}{|c|}{$\begin{array}{l}\text { Composition of } \\
\text { model mixture }\end{array}$} & \multirow{2}{*}{$\begin{array}{l}\text { ntroduced } \\
\mathrm{Cr}, \mu \mathrm{g}\end{array}$} & \multirow[t]{2}{*}{$\begin{array}{l}\text { Found } \\
\text { Cr, } \mu \mathrm{g}\end{array}$} & \multirow[t]{2}{*}{$\mathbf{s}_{r}$} \\
\hline $\mathrm{Y}, \mathrm{mg}$ & $\mathrm{Al}, \mathrm{mg}$ & & & \\
\hline \multirow{3}{*}{2.1} & \multirow{3}{*}{1.1} & 3.0 & $2.99 \pm 0.18$ & 0.04 \\
\hline & & 4.5 & $4.27 \pm 0.12$ & 0.02 \\
\hline & & 6.0 & $5.94 \pm 0.10$ & 0.01 \\
\hline
\end{tabular}

In most cases $\mathrm{KMnO}_{4}$ excess is removed by means of sodium azide. For this purpose we used sodium nitrite, less expensive and more available. As the reaction of the interaction of $\mathrm{NaNO}_{2}$ with $\mathrm{KMnO}_{4}$ is rather slow, the reductant solution must be added gradually, drop-by-drop at intervals of 30-40 sec. Thereat, the solution was thoroughly mixed after addition of each drop till the solution bleached. Then the colourless solution was transfer into $50 \mathrm{ml}$ volumetric flask containing diphenylcarbazide and diluted with water to mark. In 10-15 min. the absorbance of the obtained solution was measured at $546 \mathrm{~nm}$ wavelength versus blank solution. The colour of the complex of Cr(III) with diphenylcarbazone in 0.03-0.05 M $\mathrm{H}_{2} \mathrm{SO}_{4}$ is the most intense and stable at least for an hour. Changes of the diphenylcarbazide concentration in the range of $0.002-0.005 \%$ do not influence the measurement results.

Absorbance of the solution $(A)$ is proportional to the Cr(VI) concentration in 0.01$0.2 \mu \mathrm{g} / \mathrm{ml}$ range. The graduation graph is described by the equation: $A=$ (3.150 \pm 0.034$) \mathrm{c}$, the free member value is insignificant, the correlation coefficient is equal to 0.9998 .

The developed technique was tested according to the scheme "introduced-found" on model mixtures consisting of yttrium aluminium garnet without chromium addition and chromic potassium alum. The testing results showed the absence of a significant systematic error (Table 1). The main components of the optical ceramics which content in the sample exceeded the one of $\mathrm{Cr}$ by several hundred fold did not influence the determination of chromium.

Table 2 contains the results of the analysis of Cr:YAG sample at different stages of the obtaining of the ceramics. At chromium determination the relative standard deviations of single results calculated for three
Table 2. Results of chromium determination in Cr:YAG $(n=3, P=0.95)$

\begin{tabular}{|c|c|c||}
\hline $\begin{array}{c}\text { Sample } \\
\text { number }\end{array}$ & $\begin{array}{c}\text { Annealing } \\
\text { temperature }\end{array}$ & Found Cr, \% \\
\hline 1 & - & $0.038 \pm 0.003$ \\
& $600^{\circ} \mathrm{C}$ & $0.038 \pm 0.004$ \\
& $800^{\circ} \mathrm{C}$ & $0.038 \pm 0.005$ \\
& $1000^{\circ} \mathrm{C}$ & $0.035 \pm 0.002$ \\
& $1750^{\circ} \mathrm{C}$ & $0.029 \pm 0.001$ \\
\hline 2 & - & $0.41 \pm 0.004$ \\
& $600^{\circ} \mathrm{C}$ & $0.42 \pm 0.004$ \\
& $1750^{\circ} \mathrm{C}$ & $0.35 \pm 0.002$ \\
\hline
\end{tabular}

experiments with a confidence coefficient of 0.95 , are $0.01-0.05$.

\section{Conclusions}

Developed is a reliable sensitive technique for spectrometric determination of 0.005 to $0.3 \%$ wt. of chromium in Cr:YAG optical ceramics without preliminary separation from the main elements of ceramics. The determination error is characterized by a relative standard deviation of $0.01-0.05$.

Established are the conditions of $\mathrm{Cr}(\mathrm{III})$ oxidation with potassium permanganate. It is shown that the use of sodium nitrite for reduction of excess of $\mathrm{KMnO}_{4}$ results in the obtaining of correct and reproducible results of chromium determination provided that the chosen conditions are strictly observed.

\section{References}

1. M.Vovk, M.A.Chaika, N.A.Dulina, A.G.Doroshenko, in: Book Abstr. Int. Res. and Pract. Conf. "Nanotechnology and nanomaterials" (NANO-2015), Lviv, Ukraine (2015), p.501.

2. N.Il'ichev, E.S.Gulyamova, P.P.Pashinin, Quant. Electron., 27, 972 (1997).

3. J.Willems, N.M.Blaton., O.M.Peeters, C.J.DeRanter, Anal.Chim.Acta, 88, 345 (1977).

4. V.Maheswari, N.Balasubramanian, Chem. Anal. (Warsaw), 41, 569 (1996).

5. B.Narayana, T.Cherian, J.Braz.Chem.Soc., 16, 197 (2005).

6. T.Cherian, B.Narayana, Indian J.Chem.Technol., 12, 596 (2005).

7. H.Sereshti, M.Vasheghani Farahani, M.Baghdadi, Talanta, 146, 662 (2016).

8. M.Derbyshire, A.Lamberty, P.H.E.Gardiner, J.Anal.Chem., 71, 4203 (1999).

9. M.Sperling, S.Xu, B.Welz, J.Anal.Chem., 64, 3101 (1992). 
10. H.I.Ulusoy, R.Gurkan, O.Yilmaz, M.Akcay, $J$. Anal. Chem., 67, 131 (2012).

11. S.Greenfield, H.McD.McGeachin, P.R.Smith, Talanta, 22, 553 (1975).

12. A.G.Coedo, T.Dorado, I.Padilla, F.J.Alguacil, J.Anal.At.Spectrom., 15, 1564 (2000).

13. S.Nikolova, T.Dobrev, M.Monev, Metal Finishing, 93, 12 (1995).

14. K.Wrobel, P.L.Lopez-de-Alba, L.Lopez Martinez, Talanta, 44, 2129 (1997).

15. T.N.Simonova, V.A.Dubrovina, A.B.Vishnikin, J.Serbian Chem.Soc., 81, 645 (2016).

16. V.Persits, Metal Finishing, 109, 26 (2011).

17. J.C.Tayone, J.Sci: Basic Appl.Res. (IJSBAR), 19, 426 (2015).
18. V.Maheswari, N.Balasubramanian, Chem. Anal.(Warsaw), 41, 569 (1996).

19. K.Tanaka, A.Ishimaru, Bunseki Kagaku, 31, 191 (1982).

20. M.Llobat-Estelles, A.R.Mauri-Aucejo, M.D.LopezCatalan, Fresenius J.Anal.Chem., 371, 358 (2001).

21. F.Umland, A.Yanssen, D.Thierig, G.Wunsch, Theorie und Practische Anwendung von Komplexbildnern, Akademischne Verlagsgesellschaft, Frankfurt am Main (1971).

22. B.Jankiewicz, B.Ptaszynski, Polish J.Environ. Studies, 14(6), 869 (2005). 